An Introduction to Medical Genetics. By J. A. Fraser Roberts. 5th edition. (Pp. xiv $+296 ; 123$ figures. Boards 50s., paper covers 35s.) London, New York, and Toronto: Oxford University Press. 1970.

Dr. Fraser Roberts' book needs no introduction to medical geneticists or to interested clinicians. It has long been by far the best first textbook on its subject and the revised edition suggests that it still has no peer. The reviewer is certainly not the only medical man who first had his interest in genetics aroused by this book.

Though the author has resisted the temptation to develop the 'introduction' into a textbook, succeeding editions have inevitably become a little longer and more difficult for a novice to follow, so that possibly an earlier edition could still be preferred first reading. On the other hand, the new edition which starts with a simple exposition of molecular genetics will seem more logical to new readers, even if, as is probably inevitable at the present time, there is no real follow-up of the information imparted in subsequent sections of the book, even in the short section on biochemical genetics. The chapters on blood group genetics and chromosomal abnormalities have been brought up to date, and there is a welcome expansion of the section on multifactorial inheritance, though the author may have written on the last subject more clearly and as economically in various review articles.

As in all previous editions the format of the book is excellent, and old and new clinical photographs are of a very high quality. Possibly the photographs of karyotypes are not quite of the same high standard.

The publishers have done remarkably well to keep the price of this book so low, and at 35/- the paperback edition in particular is extremely good value.

Alan C. Stevenson

Endocrine and Genetic Diseases of Childhood. Edited by Lytt I. Gardner. (Pp. xviii + 1072; illustrated + tables. 289s.) Philadelphia and London: W. B. Saunders. 1969.

Dr. Lytt Gardner has seemingly accomplished the formidable task of welding the contributions of no fewer than 56 of his colleagues, at home and abroad, into a readable whole. This is a most comprehensive book of the endocrine and genetic diseases of childhood. The opening chapters on normal and abnormal growth patterns span embryo and adolescent; these are followed by sections on diseases and abnormalities of the various endocrine glands, and their management. Chromosomal anomalies are fully discussed, with a section on cytological techniques; and the recording and interpretation of dermatoglyphic patterns is aligned to various well-recognized syndromes. The major disorders of biochemistry and metabolism are described, along with chapters on obesity, cystic fibrosis, the psychological aspects of endocrine and genetic diseases in children, and genetic counselling.

In the section on the intrauterine growth of embryo and foetus, one is surprised to find no mention of the relative effects of reduction of cell number and cell size. It is disappointing to find starvation of the low birthweight infant more or less condoned in the section on carbohydrate metabolism in the newborn, and no mention made of the prevention of symptomatic hypoglycaemia by adequate feeding. The differential diagnosis of ambiguous sex at birth is most clearly set out, and the importance of scrupulously careful assessment before assigning the appropriate gender role as soon as possible after birth is emphasized. The genetically determined abnormalities of biochemistry and metabolism are succinctly described, though some of the more common disorders such as cystic fibrosis get considerably less attertion for instance than some of the very rare inborn errors. In his humanely written chapter on genetic counselling, Dr. Gardner has preferred to give illustrative case histories rather than 'an exhaustive tabulation of all data available', but ample references are given for those who wish to refer to the latter.

Though few will feel they can really afford this book, many will not wish to be without it; and as a reference work in a field which has seen many rapid recent advances, it seems a thoroughly worth-while investment.

P. A. Davies

\section{A Study of the Early Development of Mongols.} Institute for Reasearch into Mental Retardation Monograph No. 1. By Valerie A. Cowie. (Pp. xiii +110 ; figures + tables +5 appendices; 60 s.; $\$ 8.00$.) Oxford: Pergamon Press. 1970.

This book represents an excellent beginning to a series of monographs on mental retardation. Dr. Cowie organized a survey in Surrey, Camberwell, and Lewisham, thus making available to her 79 infants with Down's syndrome. Only three infants were over 6 months of age when first seen. Thirteen died, mainly during the first three weeks of life; of these, 10 were girls. Developmental testing was undertaken at 6 weeks, 